Bulletin de la Société Royale des Sciences de Liège, Vol. 86, special edition, 2017, p. 869 - 890

\title{
Providing an operational model for the development and assessment of companies' social responsibility
}

\author{
(Case Study: private sector industrial manufacturing companies of Semnan Province) \\ Mohammad Ali SHARIAT \\ Department of industrial engineering, Semnan branch, Islamic Azad University, Semnan, Iran
}

\begin{abstract}
The present study aims to provide a practical model for the development and assessment of the attitude of private sector industrial manufacturing companies of Semnan province toward social responsibility of organizations. After reviewing the literature, a mixed model, which is a combination of the pattern of the Carroll pyramid, the pattern of social reporting, corporate governance issues, organizational excellence model, and ISO 26000, is proposed, where Carroll's pattern plays a central role. In this study, four economic, legal, ethical, and humanitarian dimensions are used to meet economic responsibilities, respond to legal responsibilities, implement ethical necessities, and undertake leadership in social institutes, respectively. Accordingly, a questionnaire was prepared and distributed among the population that turned out to be 93 companies from among companies with more than 6 months activity in 2015 in Semnan province that were selected based on Morgan method. Data are analyzed using SPSS and LISREL software. Based on the results, utility of the model is reported to be high in four parts.
\end{abstract}

Keywords: Sustainable development, organizational stakeholders, Semnan, Social Responsibilities

\section{Introduction}

Since the relationship between the social, political, environmental, and economic roles in business is increasing, organizations are faced with new dynamics. The challenge organizations face is that they have to increase profitability and meet new social expectations at the same time and then manage these two seemingly contradictory outcomes that need the development of practical strategies and have positive effects on society and the organization.

Commitment to social responsibility in the organization is one of the effective mechanisms or strategies in this case. In fact, in addition to traditional duties, today organizations are required to carry out other activities aimed at meeting the expectations of society, which is called social responsibilities of organization. During this period, effective management is a management free from the limits of thinking about the organization, rather is thinking about a wider community 
and environment, because neither organizations can isolate themselves from society nor society can continue without organizations (Karnami, 2008: 2).

What is certain is that from the second half of the twentieth century, public awareness about the dependence of organizations, society and the environment on each other has increased and everyone realized that, on the one hand, organizations achieve their goals by relying on the facilities available at community and on the other hand, organizations' measures should have interests and achievements for the society. Hence, it has always been attempted to defined interests in organizations in such a way that people of the society benefit more than the cost they have paid and, in a sense, in addition to profit creation, organizations should have value creation. In fact, organizations must accept that they have a public and social role in order to maintain social legitimacy and guarantee their survival. If managers do not respect their social objectives, environmental contamination, disease, discrimination and stigma will occupy their environment and these problems will finally afflict them if they don't foresee them (Omidvar, 2007: 14). Ethical and social responsibility, continuous commitment of the owners of industry, commerce and government require them to observe ethics and economic development along with the improvement of the living standards of workers and their families in society at large. In addition, corporate social responsibility, commitment of business and industry owners to the community should consider job opportunities for production, workforce skills, community and government while respecting different cultures. Mullen also believes that corporate social responsibility management is like managing other parts of the company. He says you can do it well or you can do it badly. If the process of social responsibility management stops you from doing other important things, this does not mean the nature of managing social issues has problem, rather, the problem is the way you have done it. The proper management of social responsibilities can well support economic goals, can establish good relationships with investors, whose idea about the working process in times of crisis is very important, and can decrease costs and increase profitability (Omidvar, 2007: 17). This is also of importance in economic activities of Semnan province, given its selection as "City of Ethics" and given the increasing investment in the province. Accordingly, providing a model for the development of ethics, social responsibilities, and assessment of the processes and identification of factors affecting the debate seems necessary.

\section{Theoretical Foundations}

There is no clear definition of corporate social responsibility with an academic approach and the formation of a dominant model of corporate social responsibility dates back to 1920 in the academic literature. It should be noted that modern attention to the development of corporate social responsibility begins to grow when both academic and management literatures start to set corporate social responsibilities (Perrin, 2006, 306). The oldest mention to corporate social responsibility was in 1953, when Bowen provided a definition of corporate social responsibility as "business and merchants' commitment to pursue those policies, decisions and activities that are desirable in terms of the objectives and values of the community"(Choi and Gary, 2008: 
343). The term "corporate social responsibility" is defined through its three constituting words, i.e. corporate, society, and responsibility. Therefore, corporate social responsibility can be described as a business activity or corporate accountability that protects the society where it works (Zhu and Tan, 2008: 761). Smith (2003) defines corporate social responsibility as "the process of creating wealth, improving the company's competitive advantage and maximizing the value of the wealth generated for the community, which considers the overall business commitment, attention to the quality of life of employees, customers, the local community and the whole society to achieve sustainable economic development" (Holm and Watts, 2000: 3). In other words, "social responsibility of a business is an excellence approach to business that considers the social impact of an organization on the society, both internally and externally, with the goal of aligning economic benefits with the environment and sustainable development of business "(Omidvar, 2007: 32). Corporate social responsibility is often divided to economic, social and environmental sections, the same as the division provided in the general concept of sustainable development. According to the International Center for Sustainable Development of Business, corporate social responsibility is defined as "business commitments in considering sustainable economic development, working with employees, families, the local community and society in general to improve the quality of life" (Karna et al., 2004: 849). Corporate social responsibility has also been in the form of humanitarian and charity activities since 1920, when powerful businessmen such as Carnegie and Ford spent their own budget for charity purposes in order to enhance the social conditions. Modern concepts of corporate social responsibility in the $60 \mathrm{~s}$ in the United States were mainly created with the idea that companies have other responsibilities beyond their legal obligations. Corporate social responsibility is defined as a policy and technique beyond legal obligations and in order to cause profitability for the whole society. According to the definition in the society, the principle of corporate social responsibility is considered as a fundamental principle and businesses that have a role in promoting community have been more successful than those who have excluded themselves.

\section{Research background}

To better understand the issue, it is important to review the theories and approaches to corporate social responsibility (see Table 1) so as to understand the change of approaches and views and the development of the concept and its common models from 1950 onwards.

Table 1: Theories of Corporate Social Responsibility from the 1950s to the present

\begin{tabular}{|c|c|c|}
\hline $\begin{array}{c}\text { Theory / } \\
\text { Approach }\end{array}$ & Date & Focus of theory / approach \\
\hline $\begin{array}{c}\text { Social } \\
\text { responsibility }\end{array}$ & $1950 \mathrm{~s}$ & $\begin{array}{r}\text { Bowen (1953): social responsibility refers to business custodians' commitment to pursue } \\
\text { policies, take decisions and implement the measures that are desirable in terms of the } \\
\text { objectives and values of the community. }\end{array}$ \\
\hline $\begin{array}{c}\text { Social } \\
\text { responsibility }\end{array}$ & $1960 \mathrm{~s}$ & $\begin{array}{r}\text { Davis (1960): Attitude of social responsibility to responsible business decisions necessary } \\
\text { to gain an economic advantage for the company. } \\
\text { McGuire (1963): the idea of social responsibility assumes that not only the organization has } \\
\text { economic and legal obligations, but also it has certain responsibilities towards society. }\end{array}$ \\
\hline
\end{tabular}




\begin{tabular}{|c|c|c|}
\hline & & $\begin{array}{l}\text { Davis and Blastroum (1966): social responsibility refers to a person's commitment to } \\
\text { considering the impact of decisions and actions on the entire social system. } \\
\text { Walton (1967): the new concept of social responsibility recognizes the intimacy of the } \\
\text { relationship between the organization and the community and understands that such a } \\
\text { relationship should be remembered by senior managers, as organizations and affiliated } \\
\text { groups pursue their relative goals. }\end{array}$ \\
\hline $\begin{array}{l}\text { Corporate social } \\
\text { responsibility }\end{array}$ & $1970 \mathrm{~s}$ & $\begin{array}{l}\text { Else and Walton (1974): Social responsibility shows concern about the needs of society and } \\
\text { goes beyond mere economics. } \\
\text { Beckman (1975) - Social responsibility usually refers to the goals and incentives that } \\
\text { should be weighted by businesses, which include objectives that are also concerned with } \\
\text { economic performance. }\end{array}$ \\
\hline $\begin{array}{l}\text { Corporate social } \\
\text { responsibility }\end{array}$ & 1980s & $\begin{array}{l}\text { Jones (1980) - Corporate social responsibility is a symbol of commitment towards forming } \\
\text { groups in the community, except stakeholders, and goes beyond what is specified in union }\end{array}$ \\
\hline $\begin{array}{l}\text { Social } \\
\text { responsibility }\end{array}$ & & $\begin{array}{l}\text { Tazolina and Armandi (1981) - Organizations, like people, have criteria that must be met } \\
\text { and, as shown in Maslow's hierarchy, organizations are the same. }\end{array}$ \\
\hline $\begin{array}{c}\text { Social } \\
\text { accountability }\end{array}$ & & $\begin{array}{l}\text { Dalton and Kuzar (1982) - they provided a model that shows a } 2 \times 2 \text { matrix, with "legal" and } \\
\text { "illegal" on one axis and "responsible" and "irresponsible" on the other axis. They conclude } \\
\text { that the cell "legal-responsible" is the proper CSR strategy for companies. }\end{array}$ \\
\hline Social response & & $\begin{array}{l}\text { Strand (1983): proposed the model of organizational adaptation to the social environment } \\
\text { that seeks is to show that such related concepts, such as social responsibility, social } \\
\text { accountability and social response, are linked to the organization-environment model. }\end{array}$ \\
\hline $\begin{array}{l}\text { Corporate Social } \\
\text { Performance }\end{array}$ & & $\begin{array}{c}\text { Carol (1983) - CSR is composed of four parts: economic, legal, ethical, and voluntary or } \\
\text { humanitarian. }\end{array}$ \\
\hline & & $\begin{array}{c}\text { Drucker (1984): offered a "new concept" of CSR - Business should turn its social } \\
\text { responsibility to business opportunities. }\end{array}$ \\
\hline & & $\begin{array}{l}\text { Freeman (1984) - Relations of a company with stakeholders (and the behavior of the } \\
\text { natural environment) are the core of understanding how can be acted as a business so that } \\
\text { value added is added. }\end{array}$ \\
\hline & & $\begin{array}{c}\text { Vartick and Cochran (1985): proposed the evolution of corporate social performance model } \\
\text { that generalized three-dimensional integrity of responsibility, accountability and social } \\
\text { issues. }\end{array}$ \\
\hline $\begin{array}{l}\text { Corporate social } \\
\text { responsibility }\end{array}$ & $1990 \mathrm{~s}$ & $\begin{array}{l}\text { Wood (1991) proposed CSR principle adopted from the four areas of Carol (1979) } \\
\text { (economic, legal, ethical, and humanitarian). Firstly, he specified how the social principles } \\
\text { of legality (institutional level) of CSR are related to general liability (organizational level), } \\
\text { and the discretion of management (individual level). Secondly, he identified processes of } \\
\text { corporate social accountability that is beyond expression of response categories (passive, } \\
\text { defensive, adaptive, proactive) and he specified such processes as environmental } \\
\text { assessment, stakeholder management, and issues' management. Thirdly, he adopted Vatrick } \\
\text { and Cochran's (1985) policies and recognized them as a new issue of the consequences of } \\
\text { organizational behavior. } \\
\text { Carol (1991) - four types of social responsibility constitute the entire CSR: economic, } \\
\text { ethical, legal and humanitarian. In addition, these four categories or components of CSR } \\
\text { should be shown in the form of a pyramid. } \\
\text { Freeman (1994) - stakeholders' language was used widely in practice and the concepts of } \\
\text { responsibility / corporate citizenship were collected by researchers who found that } \\
\text { responsibility / corporate citizenship are expressed due to decisions, actions and impacts of } \\
\text { a company on stakeholders and the natural environment. }\end{array}$ \\
\hline
\end{tabular}


Bulletin de la Société Royale des Sciences de Liège, Vol. 86, special edition, 2017, p. 869 - 890

\begin{tabular}{|c|c|c|c|}
\hline $\begin{array}{c}\text { Corporate social } \\
\text { responsibility }\end{array}$ & $2000 \mathrm{~s}$ & $\begin{array}{c}\text { Garyga and Molly (2004): divided theories of corporate social responsibility into four } \\
\text { groups: instrumental, political, aligning, and ethical. These groups could be considered as } \\
\text { the development stages of corporate social responsibility. }\end{array}$ \\
\hline
\end{tabular}

If we want to classify and summarize thoughts proposed in the field of corporate social responsibility and their differences and similarities, we can show them in Table 2.

Table 2: Historical perspectives on the management ideas of social responsibility

\begin{tabular}{|c|c|c|c|}
\hline Thoughts & $\begin{array}{c}\text { Phase } 1 \\
\text { Management based on } \\
\text { maximum profit gaining } \\
\text { (1800s-1930s) }\end{array}$ & $\begin{array}{c}\text { Phase } 2 \\
\text { Trust-based management (1930s-early } \\
1960 \mathrm{~s})\end{array}$ & $\begin{array}{c}\text { Phase } 3 \\
\text { Management of life quality (late } \\
\text { 1960s-present) }\end{array}$ \\
\hline Orien & 1. just personal interests & $\begin{array}{l}\text { 1. Personal interests } \\
\text { 2. Interests of stakeholders and } \\
\text { concerned individuals of the } \\
\text { organization }\end{array}$ & $\begin{array}{l}\text { 1. Personal interests } \\
\text { 2. Interests of stakeholders and } \\
\text { concerned individuals of the } \\
\text { organization } \\
\text { 3. Interests of society }\end{array}$ \\
\hline $\begin{array}{c}\text { Economic } \\
\text { values }\end{array}$ & $\begin{array}{l}\text { 1. What is good for me, is } \\
\text { also good for the society } \\
\text { 2. maximizing profits } \\
\text { 3. Money and health are the } \\
\text { most important things. } \\
\text { 4. We shouldn't let the } \\
\text { buyer know anything. } \\
\text { 5. Labor is like a good that } \\
\text { can be sold and bought. } \\
\text { 6. Management is just } \\
\text { accountable for owners. }\end{array}$ & $\begin{array}{l}\text { 1. What is good for me, is also good for } \\
\text { the society } \\
\text { 2. Profits at a sufficient level } \\
\text { 3. Money is important, but people are } \\
\text { also important } \\
\text { 4. We shouldn't beguile customers } \\
\text { 5. Labor has its own rights that should } \\
\text { be taken into account. } \\
\text { 6. Management is accountable for } \\
\text { customers, owners, employees, } \\
\text { suppliers, and other stakeholders. }\end{array}$ & $\begin{array}{l}\text { 1. What is good for me, is also } \\
\text { good for the society } \\
\text { 2. Profit is necessary. } \\
\text { 3. People are more important } \\
\text { than money. } \\
\text { 4. Customers should be given } \\
\text { the required information. } \\
\text { 5. Labor should be respected in } \\
\text { any aspects. } \\
\text { 6. Management is accountable } \\
\text { for owners and society. }\end{array}$ \\
\hline
\end{tabular}

\section{Models of corporate social responsibility}

In recent years, various models have been employed by different organizations and social groups, but in this study, a combined model that is a combination of Carroll's pyramid framework, social reporting model, corporate governance model, organizational excellence model and the standard of ISO 26000 is used. In this hybrid model, Carroll's pyramid has a central place; in the following lines, the importance of this model and reasons the model has been chosen are emphasized.

- After 50 years of research in the field of corporate social responsibility, Carroll's 4-component model is the most widely used and most cited model in literature.

- Carroll's model is simpler and more understandable than other models. 
- After being proposed about 30 years ago, the model has been revised several times in the most prestigious management journals under the guise of Carroll (In 1979, 1983, 1991.1994, 1998, 2000, and 2004).

- A large number of empirical researches has been done to test this model extensively. For example, studies of Aprel, Carroll and Hotfield (1985) and Pixon and Carroll (1994).

- In the few studies of this type in Iran, this model has been mostly used.

Given that the aim of this study is not just measuring and analyzing the field of social responsibility, but rather it aims to propose a developmental model, and according to the library and internet studies, a combination of GRI model, organizational excellence, corporate governance model and ISO 26000 standard along with the main principles of Carroll's model are used in the model. In fact, by taking advantage of other models, it is attempted to add the aspects that can serve to broaden the scope of application of hybrid developmental approach to Carroll's model. Of course, it is tried to maintain the integrity of the final model, and its various dimensions complement each other.

\section{The theoretical framework}

Based on the above models, development model of social responsibility (conceptual model of research methodology) is presented in Figure 1: 

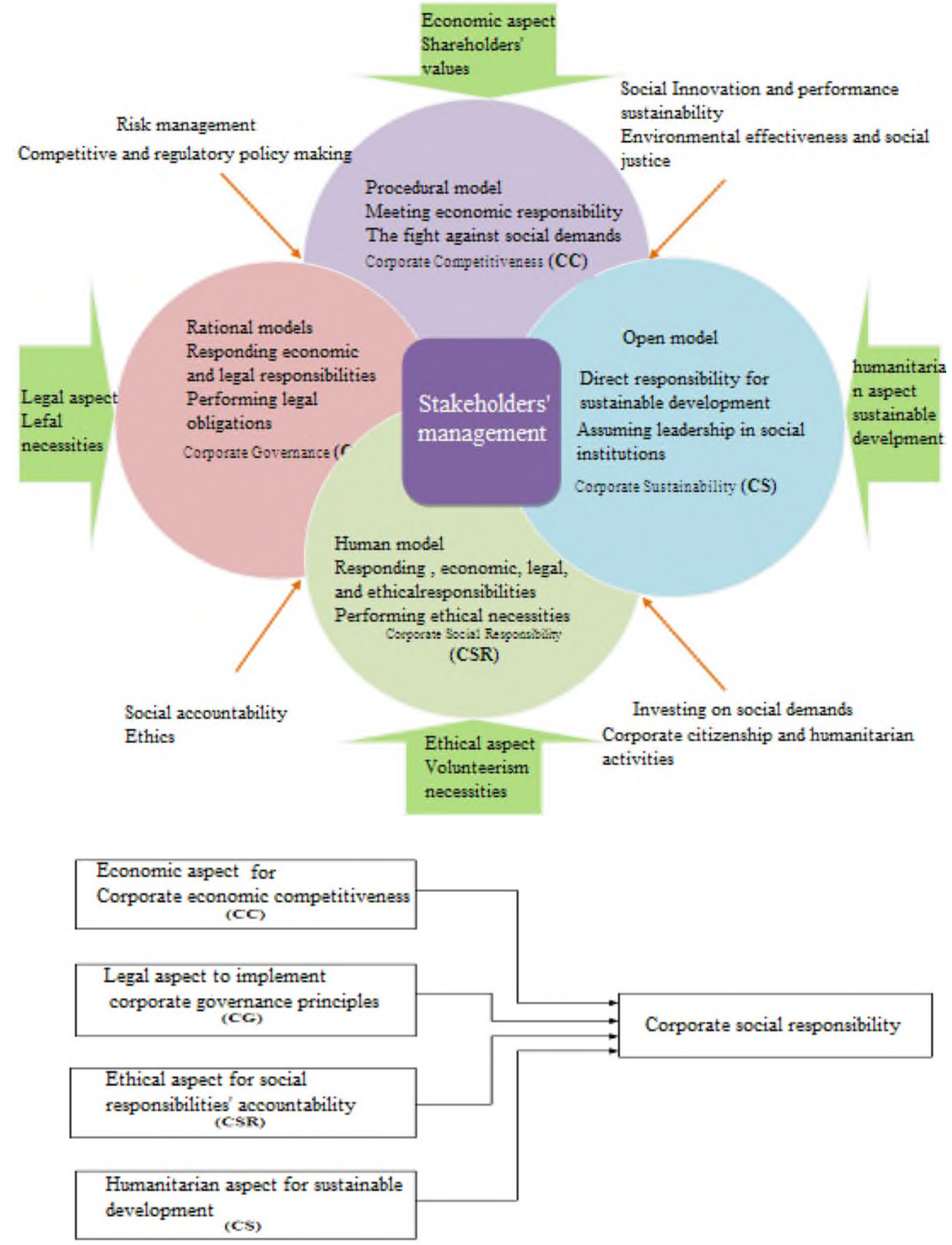

Figure 1: Conceptual model of the study

\section{Research methodology}

The present study is a survey research that can be considered a developmental research in terms of its result. To determine the factors affecting the adoption, implementation and development of corporate social responsibility in Semnan province, 4 different areas on the basis of a conceptual 
framework methodology in proposing a development model for Corporate Social Responsibility in industrial production companies in Semnan province are used. In the theoretical framework of the study, it is attempted to use theoretical resources, i.e. university resources, articles, and university professors and experts, and operational resources, i.e. benchmarking successful experience of countries, both developing and developed, simultaneously. The research environment is a natural environment and studies are field studies. The unit of analysis in this study is organizations and the time horizon of the cross-sectional study is from April 2015 to March 2016. The study population included industrial manufacturing companies of the private sector active over six months in 2015 in Semnan province, which is 241 companies according to industry and trade organizations' report (Setad System). Stratified random sampling method was used to choose the sample. Based on Morgan table, the sample size turned out to be 148 companies and based on Cochran method, the sample size turned out to be 250 companies. On the other hand, since the population size is small and sample size is half of the population size, the sample size was determined to be 90 companies using the modified sampling formula. To ensure that the exact number of 90 questionnaires will be returned, 110 questionnaires were distributed.

$\mathrm{n}^{\prime}=\mathrm{n} /(1+(\mathrm{n} / \mathrm{N}))$

$\mathrm{N}=241 \quad / \quad \mathrm{n}=148 \quad / \quad \mathrm{n}^{\prime}=90$

\subsection{Data collection and analysis methods}

Data collection method is based on analysis of documents, questionnaires and in some cases, interviews and data are both quantitative and qualitative. The questionnaire has been designed based on Reitman's questionnaire design guideline (1979) (quoted in Bazargan, 2012). The validity of the questionnaire was confirmed based on the use of reliable sources of social responsibility or previous researches such as the measurement system of supply ethical data exchange (SEDEX), 2012 China International Award Inventory in the field of Corporate Social Responsibility, inventory of Corporate Social Responsibility in Europe, guide to social responsibility in UN agencies, questionnaire of NGOs responsible for social responsibility in Europe, and also questions were discussed with experts including university professors and custodians of sustainable development, which has confirmed the content validity of the questionnaire. Cronbach's alpha coefficient was used for checking its reliability. For this purpose, the researcher-made questionnaire was randomly sent to 25 companies and Cronbach alpha coefficient was calculated, which turned out to be .946 that is indicative of high reliability. The analysis was based on descriptive and inferential statistics. Descriptive statistics such as frequency tables, bar charts, and central and dispersion parameters and some inferential statistics such as Pearson correlation and structural equation modeling were used to analyze the data. All data analyses were performed using SPSS and LISREL software. 


\subsection{Data analysis}

In this study, confidence level is considered to be $95 \%$ and normality of data was descriptively checked using the normal probability plot and histogram and it was inferentially checked using Kolmogorov-Smirnov test.

Reliability: In the first step, reliability of the questionnaires were evaluated. Since the value of Cronbach's alpha is .95 and is greater than .7, the reliability of the questionnaire is confirmed. Inferential analysis: As described in the model, corporate social responsibility has 4 aspects (indices), the sum of which indicates the degree of social responsibility. At $95 \%$ confidence level, the p-value obtained for each of the variables (Table 3) is compared by .05. The desired confidence interval for all variables, except for humanitarian aspect (CS), is positive, which means that these variables are in a good level in surveyed companies. Since the desired confidence interval in the case of humanitarian aspect (CS) is negative, it means that the variable is in a poor level in the surveyed companies.

Table 3: Comparison of mean and constant values

\begin{tabular}{|c|c|c|c|c|c|c|c|c|}
\hline Variable & $\begin{array}{c}\text { Sample } \\
\text { size }\end{array}$ & Mean & SD & $\begin{array}{c}\mathrm{t}- \\
\text { statistics }\end{array}$ & $\mathrm{p}$-value & \multicolumn{2}{|c|}{$\begin{array}{c}\text { 95\% confidence } \\
\text { interval }\end{array}$} & Status \\
\cline { 5 - 8 } & & & & $\begin{array}{c}\text { Lower } \\
\text { limit }\end{array}$ & $\begin{array}{c}\text { Upper } \\
\text { limit }\end{array}$ & \\
\hline $\begin{array}{c}\text { Social } \\
\text { responsibility }\end{array}$ & 89 & 3.61 & .66 & 12.072 & .000 & .4642 & .7976 & Appropriate \\
\hline $\begin{array}{c}\text { Economic } \\
\text { aspect (CC) }\end{array}$ & 90 & 3.83 & .76751 & 10.344 & .000 & .6761 & .9976 & Appropriate \\
\hline $\begin{array}{c}\text { Legal aspect } \\
\text { (CG) }\end{array}$ & 93 & 4.13 & .75924 & 14.363 & .000 & .9745 & 1.2872 & Appropriate \\
\hline $\begin{array}{c}\text { Humanitarian } \\
\text { aspect (CS) }\end{array}$ & 93 & 2.75 & .82529 & -2.898 & .005 & -.4180 & -.0781 & Inappropriate \\
\hline $\begin{array}{c}\text { Ethical aspect } \\
\text { (CSR) }\end{array}$ & 92 & 3.63 & .68924 & 8.813 & .000 & .4905 & .7760 & Appropriate \\
\hline
\end{tabular}

Table 4: Investigation of correlation

\begin{tabular}{|c|c|c|}
\hline \multicolumn{2}{|c|}{} & Social responsibility \\
\hline \multirow{3}{*}{ Economic aspect (CC) } & Correlation coefficient & $.891^{* *}$ \\
\cline { 2 - 3 } & p-value & .000 \\
\cline { 2 - 3 } & No. & 89 \\
\hline \multirow{3}{*}{ Legal aspect (CG) } & Correlation coefficient & $.886^{* *}$ \\
\cline { 2 - 3 } & p-value & .000 \\
\cline { 2 - 3 } & No. & 89 \\
\hline \multirow{3}{*}{ Ethical aspect (CSR) } & Correlation coefficient & $.792^{* *}$ \\
\cline { 2 - 3 } & p-value & .000 \\
\cline { 2 - 3 } & No. & 89 \\
\hline
\end{tabular}


Bulletin de la Société Royale des Sciences de Liège, Vol. 86, special edition, 2017, p. 869 - 890

\begin{tabular}{|l|c|c|}
\hline \multirow{3}{*}{ Humanitarian aspect (CS) } & Correlation coefficient & $.895^{* *}$ \\
\cline { 2 - 3 } & p-value & .000 \\
\cline { 2 - 3 } & No. & 89 \\
\hline
\end{tabular}

Comparison of the obtained p-values with the error level of .05 shows that there is a significant correlation between social responsibility and economic aspect, legal aspect, ethical aspect, and humanitarian aspect.

\section{Modeling and structural equations}

In this section, variables of the study are named as follows:

\begin{tabular}{|c|c|c|}
\hline Variable & Symbol in sub-models & Symbol in the main model \\
\hline Duration of firm's establishment & var0 & D1 \\
\hline Type of activity & var11 & D2 \\
\hline Number of Staff & var12 & D3 \\
\hline $\begin{array}{c}\text { Gender Composition of the } \\
\text { Board of Directors }\end{array}$ & var13 & D5 \\
\hline The city of factories & var14 & D6 \\
\hline $\begin{array}{c}\text { Gender segregation of } \\
\text { employees }\end{array}$ & var15 & D7 \\
\hline Economic sustainability & var17 & D8 \\
\hline Native investors & var18 & D9 \\
\hline Native Management & var19 & D11 \\
\hline $\begin{array}{c}\text { Composition of the board of } \\
\text { directors }\end{array}$ & var110 \\
management & var111 & D12 \\
\hline $\begin{array}{c}\text { Educational level of } \\
\text { Native workers }\end{array}$ & var112 & D13 \\
\hline $\begin{array}{c}\text { Positive evaluation of } \\
\text { companies and buyers }\end{array}$ & var210 & D13_1 \\
\hline $\begin{array}{c}\text { Creation of CSR requirements } \\
\text { by buyers }\end{array}$ & var2101 & D13_2 \\
\hline Its commitment Buyers & var2102 & D13_3 \\
\hline
\end{tabular}

\begin{tabular}{|l|c|}
\hline \multicolumn{1}{|c|}{ CC index } & Symbol \\
\hline Employee involvement in decision-making (the offers) & CC1 \\
\hline Implementation of quality management systems (e.g. ISO 9001) & CC2 \\
\hline The use of electronic systems and ICT & CC3 \\
\hline
\end{tabular}


Bulletin de la Société Royale des Sciences de Liège, Vol. 86, special edition, 2017, p. 869 - 890

\begin{tabular}{|l|c|}
\hline Improvement and measurement system of employee satisfaction & CC4 \\
\hline Paying attention to staff safety issues & CC5 \\
\hline Improvement and measurement system of employee satisfaction & CC6 \\
\hline Implementation of inventory control and management system & CC7 \\
\hline Implementation of production and orders planning system & CC8 \\
\hline Implementation of maintenance and repair comprehensive system & CC9 \\
\hline Implementation of human resources management system & CC10 \\
\hline Improving product quality & CC11 \\
\hline Capital management and productivity & CC12 \\
\hline Final cost Management & CC13 \\
\hline Waste Management & CC14 \\
\hline Energy management and efficiency & CC15 \\
\hline knowledge management & CC16 \\
\hline Strategic management and development of the vision and mission & CC17 \\
\hline Management of shareholders' interests & CC18 \\
\hline $\begin{array}{l}\text { Development of the above issues (economic aspect) for suppliers } \\
\text { and contractors. }\end{array}$ & CC19 \\
\hline
\end{tabular}

\begin{tabular}{|l|c|}
\hline \multicolumn{1}{|c|}{ CG index } & Symbol \\
\hline $\begin{array}{l}\text { Implementing plans and defining mechanisms of prevention of } \\
\text { financial corruption }\end{array}$ & CG1 \\
\hline Adopting national standards for products and services & CG2 \\
\hline Proper implementation of labor law and a commitment to continue it & CG4 \\
\hline $\begin{array}{l}\text { Receiving business awards and certificates associated with observer } \\
\text { organizations and partners in the community }\end{array}$ & CG5 \\
\hline Proper salary and income & CG6 \\
\hline Taxes and paying attention to tax issues & CG7 \\
\hline Transparent financial reports & CG8 \\
\hline Producing safe services and products & CG9 \\
\hline Lack of or reduced problems in court and dispute resolution councils & CG10 \\
\hline Supply management and purchasing goods fairly and legally & CG11 \\
\hline Employees' social security and health issues & CG12 \\
\hline $\begin{array}{l}\text { Development of the above issues (legal aspect) for suppliers and } \\
\text { contractors. }\end{array}$ & \\
\hline
\end{tabular}

\begin{tabular}{|l|c|}
\hline \multicolumn{1}{|c|}{ CS index } & Symbol \\
\hline Job offers for people with disabilities & CS1 \\
\hline $\begin{array}{l}\text { Considering the family of staff and development of programs } \\
\text { associated with it }\end{array}$ & CS2 \\
\hline Use of counseling experts to promote family of staff & CS3 \\
\hline Supporting institutional and national sports teams & CS4 \\
\hline
\end{tabular}




\begin{tabular}{|l|c|}
\hline $\begin{array}{l}\text { Allowing employees to participate in social activities (such as blood } \\
\text { donation at work) }\end{array}$ & CS5 \\
\hline $\begin{array}{l}\text { Implementing joint projects with universities and signing } \\
\text { cooperation agreements }\end{array}$ & CS6 \\
\hline Gifts and donations to charities and public bodies & CS7 \\
\hline Building or participating in sports, health and education facilities & CS8 \\
\hline Supporting arts and culture in society & CS9 \\
\hline $\begin{array}{l}\text { Supporting health programs (vaccination for Hepatitis and AIDS } \\
\text { education programs) }\end{array}$ & CS10 \\
\hline Help to solve the problems of drugs and alcohol & CS11 \\
\hline Contribute to the development and improvement of traffic culture & CS12 \\
\hline $\begin{array}{l}\text { help programs dealing with accidents and natural disasters as well as } \\
\text { help to fix damage caused by it }\end{array}$ & CS13 \\
\hline Development of plans for employees after retirement & CS14 \\
\hline $\begin{array}{l}\text { Development of the above issues (humanitarian aspect) for suppliers } \\
\text { and contractors. }\end{array}$ & CS15 \\
\hline
\end{tabular}

\begin{tabular}{|l|c|}
\hline \multicolumn{1}{|c|}{ CSR index } & Symbol \\
\hline Free meals in the workplace. & CSR1 \\
\hline Using the industrial psychological techniques in the company. & CSR2 \\
\hline $\begin{array}{l}\text { Using consulting experts to improve and strengthen the families of } \\
\text { employees. }\end{array}$ & CSR4 \\
\hline Energy waste management. & CSR5 \\
\hline Providing education facilities and promoting staff education. & CSR6 \\
\hline Programs of ban on smoking and smoking cessation programs. & CSR7 \\
\hline The use of appropriate heating and cooling facilities. & CSR8 \\
\hline Reducing water pollution and waste management. & CSR9 \\
\hline Use of staff with different ethnicities and nationalities. & CSR11 \\
\hline $\begin{array}{l}\text { Product lifecycle management and recycling products at the end of } \\
\text { life. }\end{array}$ & CSR12 \\
\hline $\begin{array}{l}\text { Implementation of environmental management systems (e.g. ISO } \\
14001)\end{array}$ & CSR13 \\
\hline $\begin{array}{l}\text { Implementation of health and safety management systems (e.g. } \\
\text { OHSAS 18001) }\end{array}$ & CSR14 \\
\hline The use of new energy sources. & CSR15 \\
\hline $\begin{array}{l}\text { Receiving business awards and certificates related to the primacy of } \\
\text { the organization (such as the top entrepreneur or artisan, etc.). }\end{array}$ & CSR16 \\
\hline Health in the workplace. & CSR17 \\
\hline Membership in professional associations and research centers. & CSR18 \\
\hline Organizations' behavior towards pregnant women. & CSR19 \\
\hline The employment of women in managerial positions. & \\
\hline Improving ergonomic conditions in the workplace. & \\
\hline
\end{tabular}


Bulletin de la Société Royale des Sciences de Liège, Vol. 86, special edition, 2017, p. 869 - 890

\begin{tabular}{|l|c|}
\hline Refrain from hiring children in the workplace. & CSR20 \\
\hline Manage work-life balance in the organization. & CSR21 \\
\hline $\begin{array}{l}\text { Considering the health of consumer of products and services of } \\
\text { companies. }\end{array}$ & CSR23 \\
\hline Social reporting to stakeholders. & CSR24 \\
\hline $\begin{array}{l}\text { Create and develop good public relations inside and outside the } \\
\text { organization }\end{array}$ & CSR25 \\
\hline Create and develop ethical values (ethical charters) & CSR26 \\
\hline Supplemental and life insurance of employees. & CSR27 \\
\hline $\begin{array}{l}\text { Development of the above issues (social aspect) for suppliers and } \\
\text { contractors. }\end{array}$ & \\
\hline
\end{tabular}

Structural equations for sub-models:

In this section, the four sub-indices are investigated. The aim of the evaluation is to find out whether the secondary variables are significant in the model or not, which independent variables have a significant effect on the sub-indices, and which variables don't have significant effect on the sub-indices. In the following part, the four sub-indices of CC, CG, CS and CSR are examined. Due to the sample size that is 93 people, degrees of freedom is 92 that based on the confidence interval of $95 \%$ and critical value of table, it is given the value of 1.98 .

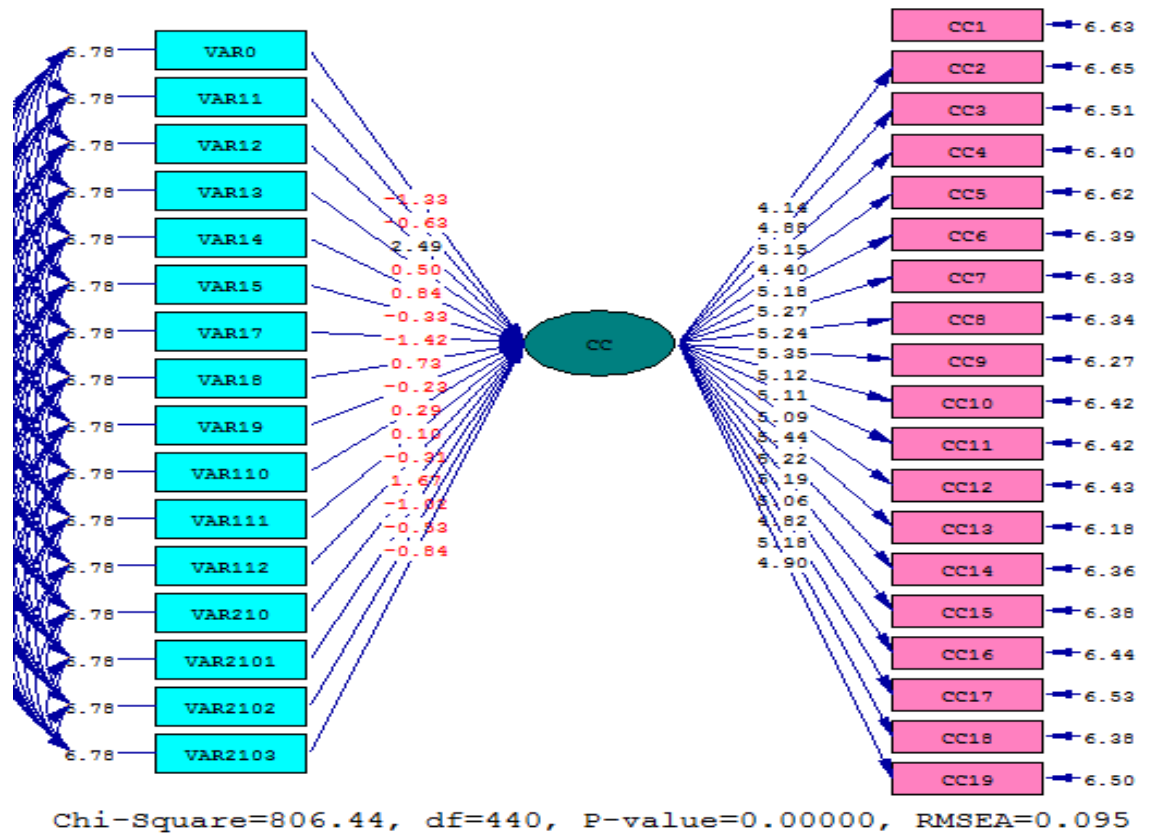

Figure 3: T-value diagram for the CC sub-index 
Bulletin de la Société Royale des Sciences de Liège, Vol. 86, special edition, 2017, p. 869 - 890

Table 4: Indices of fitness for $\mathrm{CC}$ index

\begin{tabular}{|c|c|c|}
\hline Fitness index & Desirable value & Result \\
\hline$x^{2} / d f$ & $<3.00$ & 1.83 \\
\hline GFI & $>.90$ & .91 \\
\hline RMSEA & $<.08$ & .095 \\
\hline RMR & $<.05$ & .037 \\
\hline NFI & $>.90$ & .93 \\
\hline NNFI & $>.90$ & .97 \\
\hline CFI & $>.90$ & .91 \\
\hline
\end{tabular}

Values of fitness are presented in the above table. As shown in the above table, all indices, except the RMSEA, are in a good condition, which shows that the variables are properly placed in the model and model is reliable.

CG variable:

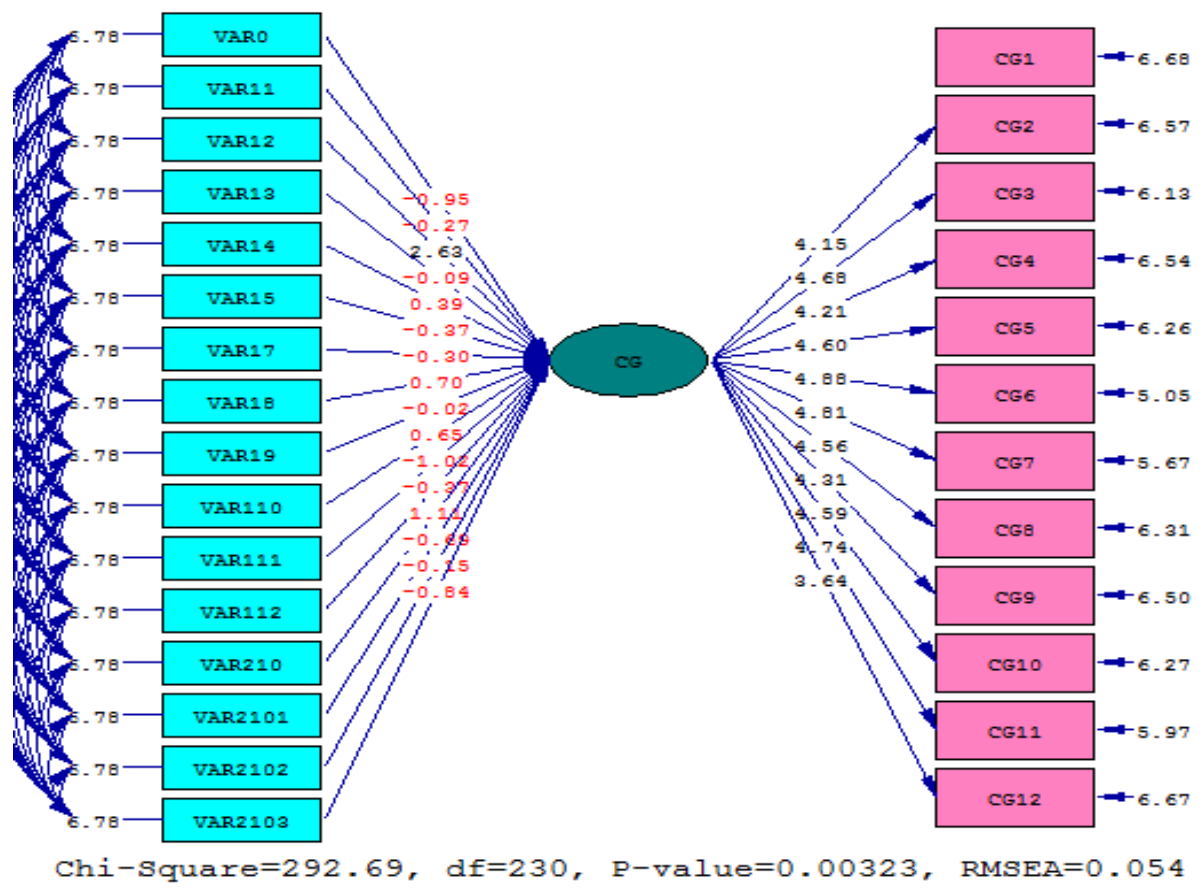

Figure 5: T-value diagram for the CG sub-index 
Bulletin de la Société Royale des Sciences de Liège, Vol. 86, special edition, 2017, p. 869 - 890

Table 5: Indices of fitness for CG index

\begin{tabular}{|c|c|c|}
\hline Fitness index & Desirable value & Result \\
\hline$x^{2} / d f$ & $<3.00$ & 1.27 \\
\hline GFI & $>.90$ & .91 \\
\hline RMSEA & $<.08$ & .054 \\
\hline RMR & $<.05$ & .041 \\
\hline NFI & $>.90$ & .90 \\
\hline NNFI & $>.90$ & .94 \\
\hline CFI & $>.90$ & .96 \\
\hline
\end{tabular}

Values of fitness are presented in the above table. As shown in the above table, all indices are in a good condition, which shows that the variables are properly placed in the model and model is reliable.

CS variable:

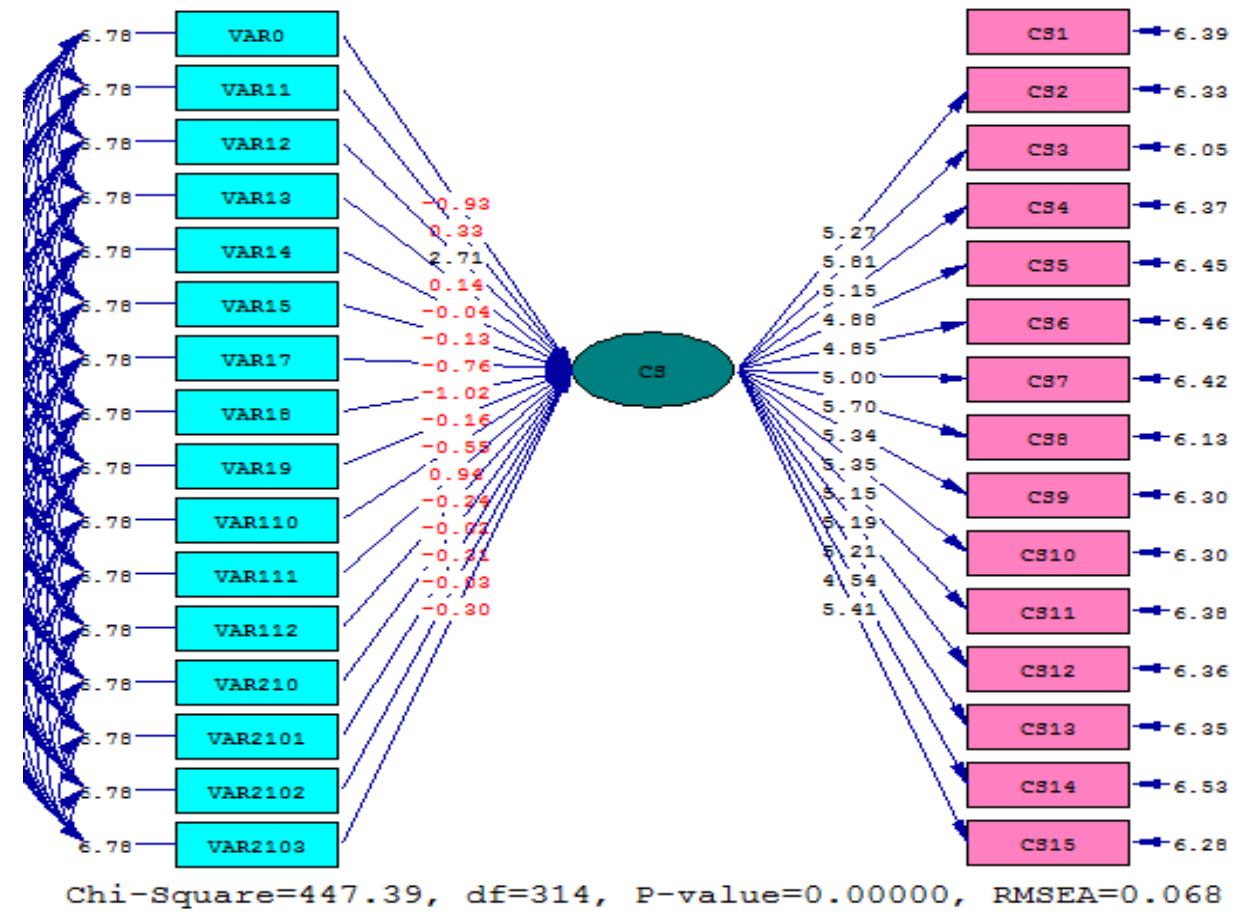

Figure 7: T-value diagram for the CS sub-index 
Bulletin de la Société Royale des Sciences de Liège, Vol. 86, special edition, 2017, p. 869 - 890

Table 6: Indices of fitness for CS index

\begin{tabular}{|c|c|c|}
\hline Fitness index & Desirable value & Result \\
\hline$x^{2} / d f$ & $<3.00$ & 1.42 \\
\hline GFI & $>.90$ & .91 \\
\hline RMSEA & $<.08$ & .068 \\
\hline RMR & $<.05$ & .02 \\
\hline NFI & $>.90$ & .92 \\
\hline NNFI & $>.90$ & .94 \\
\hline CFI & $>.90$ & .92 \\
\hline
\end{tabular}

Values of fitness are presented in the above table. As shown in the above table, all indices are in a good condition, which shows that the variables are properly placed in the model and model is reliable.

CSR variable: 
Bulletin de la Société Royale des Sciences de Liège, Vol. 86, special edition, 2017, p. 869 - 890

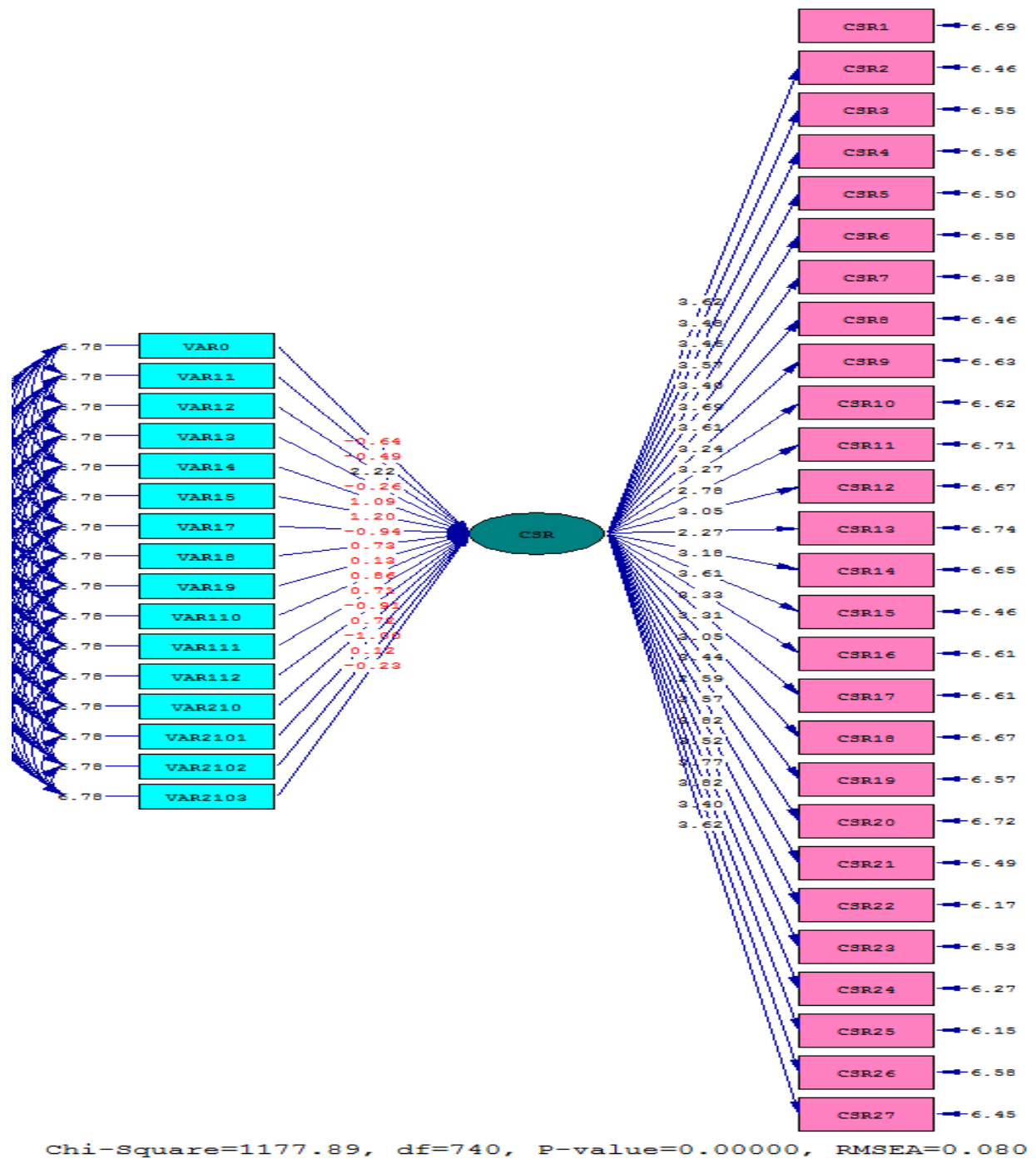

Figure 9: T-value diagram for the CSR sub-index

Table 7: Indices of fitness for CSR index

\begin{tabular}{|c|c|c|}
\hline Fitness index & Desirable value & Result \\
\hline$x^{2} / d f$ & $<3.00$ & 1.59 \\
\hline GFI & $>.90$ & .93 \\
\hline RMSEA & $<.08$ & .080 \\
\hline RMR & $<.05$ & .025 \\
\hline NFI & $>.90$ & .92 \\
\hline NNFI & $>.90$ & .93 \\
\hline CFI & $>.90$ & .94 \\
\hline
\end{tabular}


Values of fitness are presented in the above table. As shown in the above table, all indices are in a good condition, which shows that the variables are properly placed in the model and model is reliable.

Structural equations for the main model:

In this section, the main model is investigated. The model includes sub-indices and the main index. The independent variables are kept and their effect on the main index is also investigated. The main index of TCSR is predicted through four sub-hypotheses of CC, CG, CS, and CSR. As was seen before, items of the model of each sub-index were significant because their t-values are greater than 1.98 and models are also reliable.

As a result, the main index can be predicted using sub-indices.

TCSR variable:

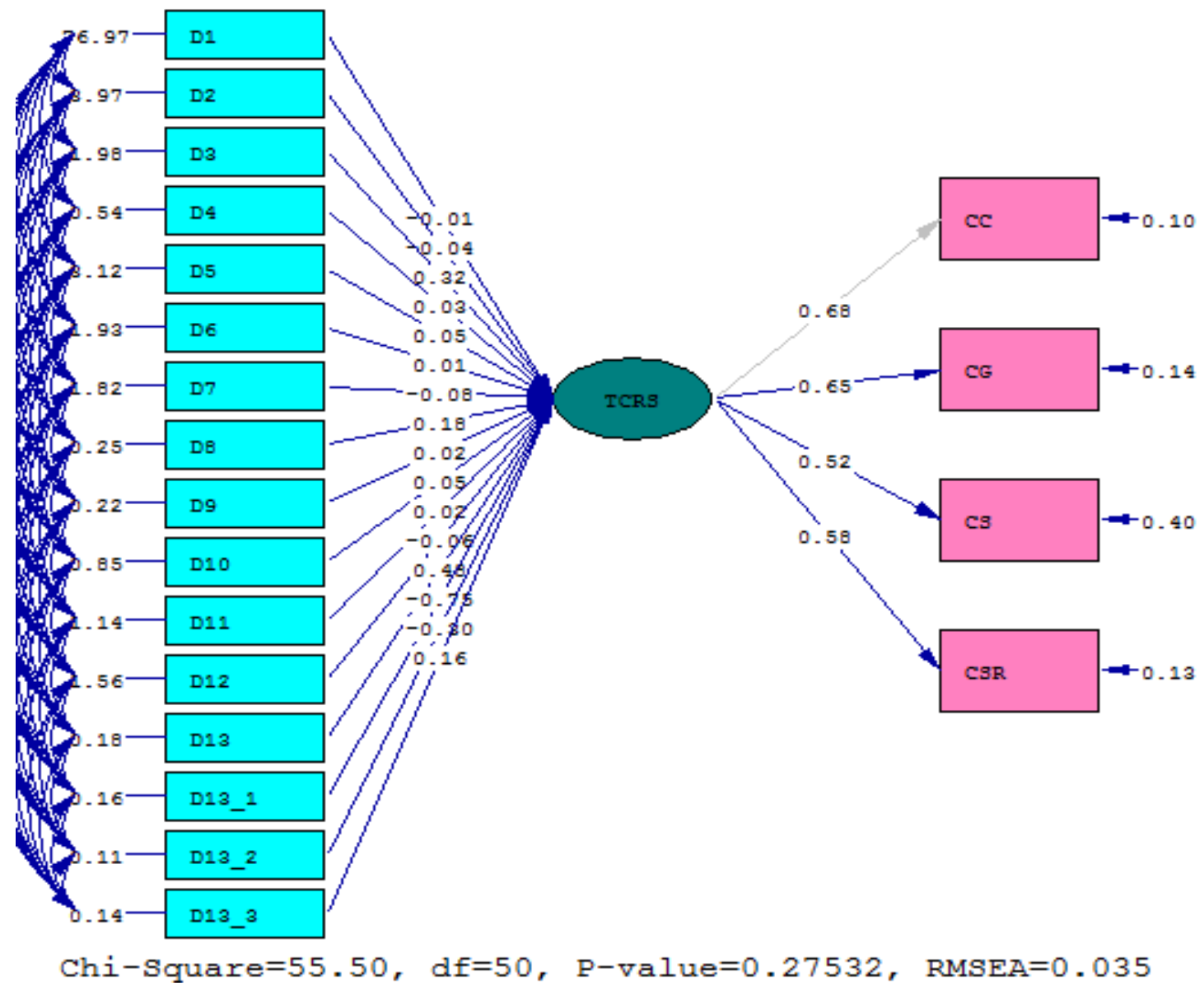

Figure 10: The main coefficients of TCSR index 
Structural Equations

$$
\begin{aligned}
& \text { TCRS }=-0.014 * \mathrm{D} 1-0.040 * \mathrm{D} 2+0.32 * \mathrm{D} 3+0.032 * \mathrm{D} 4+0.049 * \mathrm{D} 5+0.011 * \mathrm{D} 6-0.080 * \mathrm{D} 7 \\
& +0.18 * \mathrm{D} 8+0.019 * \mathrm{D} 9+0.046 * \mathrm{D} 10+0.016 * \mathrm{D} 11-0.058 * \mathrm{D} 12+0.48 * \mathrm{D} 13-0.75 * \mathrm{D} 13 \_1- \\
& 0.30 * \mathrm{D} 13 \_2+0.16 * \mathrm{D} 13 \_36 \text { Errorvar. }=0.73 \cdot \mathrm{R}^{2}=0.28
\end{aligned}
$$

The above equation is the main equation of the model. After predicting TCSR index, the effect of independent variables, which are shown as blue in the model, on the index is investigated. In LISEREl software, the effect of all variables on this index is simultaneously investigated and a multiple regression is obtained. Some variables may alone have a significant effect on TCSR index, but when all variables are simultaneously entered into the model, the effect may not be significant.

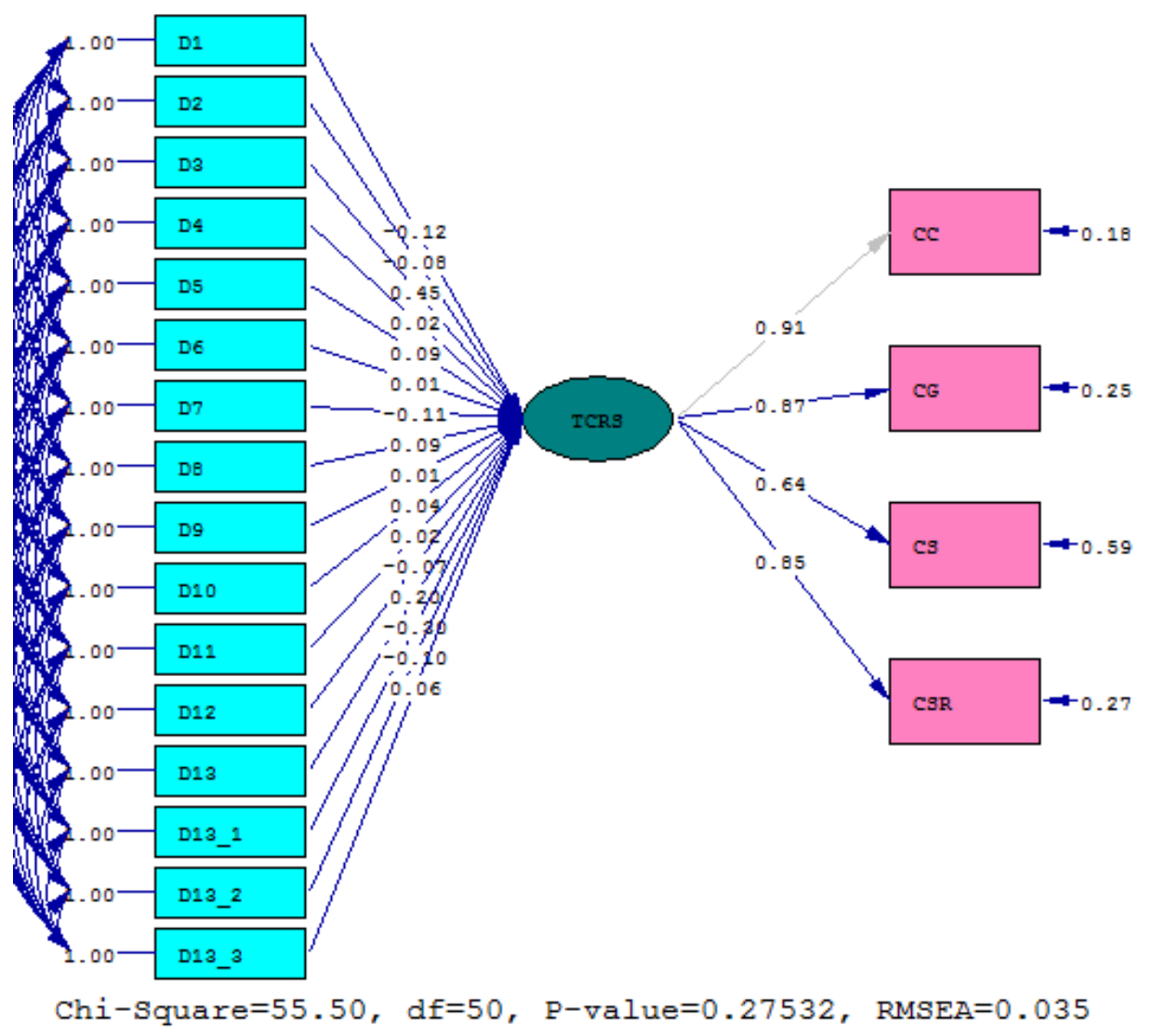

Figure 11: The standardized main coefficients of TCSR index 
Bulletin de la Société Royale des Sciences de Liège, Vol. 86, special edition, 2017, p. 869 - 890

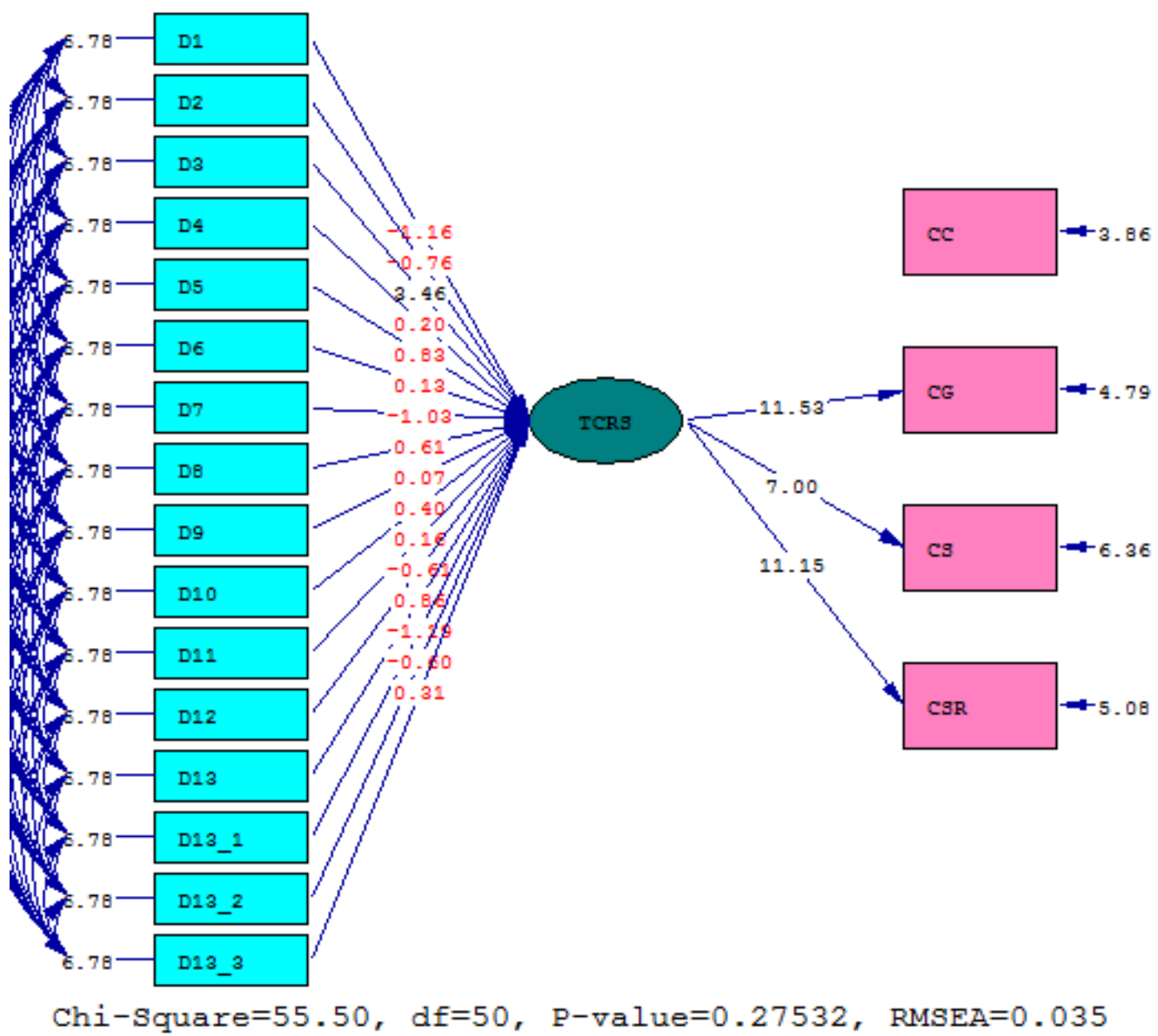

Figure 12: T-value diagram for the TCSR index

Table 8: Indices of fitness for TCSR index

\begin{tabular}{|c|c|c|}
\hline Fitness index & Desirable value & Result \\
\hline$x^{2} / d f$ & $<3.00$ & 1.11 \\
\hline GFI & $>.90$ & .94 \\
\hline RMSEA & $<.08$ & .035 \\
\hline RMR & $<.05$ & .041 \\
\hline NFI & $>.90$ & .94 \\
\hline NNFI & $>.90$ & .93 \\
\hline CFI & $>.90$ & .98 \\
\hline
\end{tabular}

Values of fitness are presented in the above table. As shown in the above table, all indices are in a good condition, which shows that the variables are properly placed in the model and model is 
reliable. If the RMSEA index is less than .08 , the model is desirable and if it is less than .05 , the model is highly desirable.

Some of the arrows in T-Value diagrams have been removed. This means that the index or variable can be a constant member of the model and is significant in any case. However, other variables may be significant in certain circumstances.

\section{Conclusion}

According to the results, status of social responsibility of the private sector industrial manufacturing companies in Semnan province is appropriate and the present situation can be improved using the obtained indices. The comparison of $\mathrm{p}$ - value with an error level of .05 shows that there is a significant correlation between social responsibility and economic aspect, legal aspect, ethical aspect, and humanitarian aspect. Based on the indices of structural fitness, the most important of which are RMSEA, NFI and GFI, all indices are in good condition, suggesting that the variables are properly placed in the model and the model is reliable and highly desirable.

\section{References}

[1] Omidvar, A.R. (2007). Corporate social responsibility, complementary and alternative to policies and tasks of the government. Master's thesis, Tehran University, Faculty of Law and Political Science. www.csriran.com.

[2] Bazargan, A., Hejazi, E., and Sarmad, Z. (2012). Research Methods in the Behavioral Sciences. Tehran: Agah Publications.

[3] Karnami, M. M. (2008). Corporate Social Responsibility strategies. Journal of Resuscitation, 26.

[4] Daft, Richard L., (1995). Organizational theory and design of the structure. Translated by Ali Parsaeian and Seyed Mohammad Arabi. Tehran: business studies and research.

[5] Hessmer, L.T. (2003): Ethics in management. Translated by Seyed Mohammad Arabi and Davoud Izadi. Tehran, Cultural Research Bureau.

[6] Gholipour, A., (2001). Sociology of organizations, sociological approach to organization and management. Tehran, SAMT publications.

[7] Rahmanseresht, H. (1998). Theory of Organization and Management. Vol. I, Tehran, Cultural Institute of Fan va Honar publications.

[8] Barnard, Ch. (1989). Managers' tasks. Translated by Mohammad Ali Toosi. The State Management Training Center.

[9] David, H. J. and Vilen, T. L. (2005). Principles of Strategic Management. Translated by Seyed Mohammad Arabi and Davoud Izadi. Tehran, Cultural Research Bureau.

[10] Fred R. D. (2003). Strategic Management. Translated by Ali Parsaeian and Seyed Mohammad Arabi. Tehran, Cultural Research Bureau.

[11] Lawson, A. (2002). Ethical management in the public service. Translated by Mohammad Reza Rabie Mendejin and Hassan Keivaryan. Tehran: Yekan publications. 
Bulletin de la Société Royale des Sciences de Liège, Vol. 86, special edition, 2017, p. 869 - 890

[12] Dessler, G. (1999). Principles of Human Resource Management. Translated by Ali Parsaeian and Seyed Mohammad Arabi. Tehran: Cultural Research Bureau.

[13] Riahi Vafa, A. (2004). Ethic-based investments in business. Tadbir monthly journal, 153.

[14] Roche, G. (2000). Social action. Translated by Homa Zanjanizadeh, Mashhad, Ferdowsi University of Mashhad, p. 44. 